\title{
Methodology of project management and type of economic mentality of managers of $x$ and $y$ generations
}

\author{
Vlada Pishchik $^{1, *}$, Alla Belousova ${ }^{1}$, Yuliya Rashchupkina ${ }^{1}$ and Aleksandr Shorokhov ${ }^{1}$ \\ ${ }^{1}$ Don State Technical University, 1, Gagarin Sq., 344000, Rostov-on-Don, Russia
}

\begin{abstract}
The article is devoted to the research of features of economic mentality of managers of the companies, representatives of different generations $(\mathrm{X}, \mathrm{Y})$ in interrelation with popular methodologies of project management. We studied the components of the economic mentality of managers $(\mathrm{N}=660)$. We used: the technique of measuring economic behavior (Lebedeva, Tatarko), the technique of measuring life meanings (Kotlyakov), technique of values (Schwartz), technique of measuring mentality (Pishchik). The group of managers of generation «X» shows the importance of the values of security, social respect and support for traditions; altruistic, existential, cognitive meanings, self-realization, there is no motive for financial economy. Rational, alarming, saving types of economic behavior prevail. One can successfully apply the methods of project management: Agile, Muda, Kanban. The group of managers of generation «Y» showed: spirituality, the value of achievement, selfdetermination, social power; the meanings of hedonism, self-realization, status, family; alarming, negative and therapeutic types of economic behavior. Project management methods can be successfully applied here: Scrum, Waterfall, Six Sigma. Focusing on the selected types of economic mentality of managers will improve the relationship between managers, participants in various projects, and will also allow you to more effectively select them in the project team.
\end{abstract}

\section{Introduction}

In the study, we offer the idea of how knowledge about the economic mentality of a manager can be applied to the methodology of project management.

«Project management» refers to a project implemented by an organization in conditions of resource constraints and providing the achievement of strategic goals [1]. However, today there are many models of project management. Muslihat (2018) [2] lists the 7 most effective project management methodologies (Agile, Scrum, Kanban, Lean methodology, Waterfall, Six Sigma, PMI) that are effective today and are selected from many others. The author understands the methodology as a system of practices and methods implemented in project management. Agile relies on teamwork and change recognition. Scrum involves coordinated teamwork based on roles in the team. Kanban is based on visualization of

*Corresponding author: vladaph@yandex.ru 
processes, feedback in team activities. Lean speaks about the client-oriented methodology. Waterfall is a linear, consistent approach to projecting. Six Sigma uses quality management techniques. PMI describes a set of standards that characterize project management. Having revealed the advantages of methodologies, the author herself implements a certain methodology when she offers the manager to choose from the listed of methods the most suitable one for a specific situation of his business development. The question is, what determines this choice?

The above mentioned methodologies, somehow, assume a certain business model and organizational culture, which is influenced by the economic mentality of managers. In our opinion, the mentality is an ideal form of expression of the meanings, senses and values of the group, embodied in its activity and in its elections. We are talking about the activity related to economic behavior. We understand economic mentality as a construct, a complex system of combining value-semantic components and socio-psychological characteristics implemented in the economic activity of certain generations [3]. Economic mentality directs the construction of models of economic behavior of a person. This understanding of mentality we implement in the framework of the socio-cultural approach.

Economic mentality is considered in various studies $[4 ; 5 ; 6 ; 7 ; 8]$. It is one of the scientific subjects of research in economic psychology. The main problem of research is determined by the need to predict human activity and behavior in the economic sphere. Analysts note the weak integration of economic psychology and economy (for example, not using methods of mathematical modeling of the economy in the descriptive constructs of psychologists). At the same time, the perspective of such interpenetration of disciplines is emphasized.

Bolton et al. (2011) [9] suggest that behavioral economic engineering is a promising area of research. They determine how behavioral phenomena can affect economic engineering. Dunning et al. (2011) [10] try to find experimental evidence that people trust in economic situations, even if their expectations of reward are relatively low, because of the motivation associated with the action of the trust itself. In our opinion, there can be a synthesis of economy and economic psychology in project management, which is based on the economic behavior of managers.

Today, we can find the analytical works of the content of articles on project management [11] and identify the most frequent topics: sustainability, sustainable development, project management triple bottom line, sustainability reporting, corporate social responsibility. Teaching processes for project activities are investigated [12]; as well as the processes of creating shared values [13]; of intuition and reflexivity in teamwork [14]; the relationship between economic decision-making and risks in the project environment [15] and many others. Values, the desire for sustainability, responsibility and the like are all manifestations of the economic mentality of managers. Economic mentality is formed under the influence of certain historical, political, and economic events. These events generate a certain system of values and meanings for certain generations in society. Each manager identifies himself with a particular generation.

In our study, the construct of economic mentality will include: type of mentality, values, meanings, type of economic behavior of generations. Each generation in society is dominated by some type of mentality. We assume that the type of mentality will determine the direction of economic behavior of the generation.

\section{Materials and methods}

The study was conducted in Rostov-on-Don. The empirical object of research were 660 people (285 men aged between 24 and 28 years, 375 women aged between 23 and 26 years), managers of companies. First, for the differentiation of respondents, we used a 
questionnaire, revealing identification with the generation. The questionnaire contained questions that referred the respondents to the Baby Boomer, X, Y generations [16]. Thus, managers were divided into 2 groups: generation X (248 people) and generation Y (412 people), with whom the respondents identified themselves. To identify the sociopsychological characteristics of the mentality we used the questionnaire that includes various aspects of economic behavior (Tatarko, Lebedeva) [17] and to identify the valuesemantic components of the economic mentality we used the method of determining the meanings of life by Kotlyakov [18], the technique of values research by Schwartz [19]. To determine the type of mentality we used the method of identifying types of mentality by Pishchik [3]. When performing mathematical processing, a computer program for statistical analysis and processing SPSS ver.21 was used.

\section{Results}

Initially, we defined the type of generational mentality. The statistics are presented in Table 1.

Table 1. Average value of mentality type.

\begin{tabular}{|l|l|c|c|c|c|}
\hline \multirow{2}{*}{$\begin{array}{c}\text { Groups of } \\
\text { generations }\end{array}$} & \multicolumn{5}{|c|}{ Mentality type } \\
\cline { 2 - 6 } & Statistics & Traditional & Innovative & Transitional & $\begin{array}{c}\text { Post- } \\
\text { Innovative }\end{array}$ \\
\hline \multirow{3}{*}{ Informational } & Average & 4.83 & 12.51 & 6.83 & 5.81 \\
\cline { 2 - 6 } & $\begin{array}{l}\text { Standard } \\
\text { deviation }\end{array}$ & 2.17 & 3.06 & 2.31 & 2.34 \\
\cline { 2 - 6 } & Dispersion & 4.71 & 9.40 & 5.36 & 5.50 \\
\hline \multirow{3}{*}{ New } & Average & 6.50 & 11.55 & 6.61 & 5.56 \\
\cline { 2 - 7 } & $\begin{array}{l}\text { Standard } \\
\text { deviation }\end{array}$ & 2.69 & 2.73 & 3.02 & 2.06 \\
\cline { 2 - 6 } & Dispersion & 7.27 & 7.47 & 9.15 & 4.25 \\
\hline
\end{tabular}

As it can be seen from the data obtained, the innovative mentality prevails in both groups. In our typology of mentality, this type is characterized by a vivid individualism.

Managers of $X$ generation have a traditional mentality with a more innovative vision of the world. Traditional mentality is characterized by collectivism attitudes, stable long-term relationships, an orderly way of life. Such managers will choose sustainable business models and strive to calculate all possible risks and strive for long-term projects.

According to the results of the identification of types of mentality, the young generation $\mathrm{Y}$ as a whole is characterized by an innovative type of mentality. This type is based on the values of vertical individualism, suggesting open relationships, an active position in life, and rationality. Apparently, the influence of traditional mentality on $\mathrm{Y}$ generation is still strong, which can affect economic behavior. We assume that managers of $\mathrm{Y}$ generation will strive for visible explicit results, the project will assume explicit movable, replaceable elements, the project life time will not be long.

Then, we measured the types of economic behavior and values in two groups. In our study, we consider economic behavior as a strategy for interacting with an economic resource. The following types of economic behavior were identified: rational, negative, alarming, therapeutic, saving. Almost all types of economic behavior were represented in groups of managers, but they were associated with different types of mentality, values and meanings. The group of managers of $\mathrm{X}$ generation was dominated by types of economic behavior: rational, alarming and saving types. The group of managers of $Y$ generation was dominated by: alarming, negative and therapeutic types of economic behavior. The next 
step was to consider the relationship between the variables in Generation X, the results of the analysis are shown in Table 2.

Table 2. Significant correlations between values and types of economic behavior in the Generation $\mathrm{X}$ group.

\begin{tabular}{|c|c|c|c|c|}
\hline Indicators & Type of economic behavior & Rational & Saving & Alarming \\
\hline \multirow{3}{*}{$\begin{array}{l}\text { Value of } \\
\text { achievements }\end{array}$} & Pearson's correlation & $0.31 *$ & -.016 & .110 \\
\hline & Value (2-sides) & .033 & .913 & .458 \\
\hline & $\mathrm{N}$ & 248 & 248 & 248 \\
\hline \multirow{3}{*}{$\begin{array}{l}\text { Value of self- } \\
\text { determination }\end{array}$} & Pearson's correlation & .189 & -.017 & $.437^{* *}$ \\
\hline & Value (2-sides) & .197 & .909 & .002 \\
\hline & $\mathrm{N}$ & 248 & 248 & 248 \\
\hline \multirow{3}{*}{$\begin{array}{l}\text { Value of } \\
\text { stimulation }\end{array}$} & Pearson's correlation & -.234 & -.229 & -.037 \\
\hline & Value (2-sides) & .110 & .118 & .804 \\
\hline & $\mathrm{N}$ & 248 & 248 & 248 \\
\hline \multirow{3}{*}{$\begin{array}{l}\text { Value of } \\
\text { conformity }\end{array}$} & Pearson's correlation & -.184 & .019 & $-.405^{* *}$ \\
\hline & Value (2-sides) & .211 & .899 & .004 \\
\hline & $\mathrm{N}$ & 248 & 248 & 248 \\
\hline \multirow{3}{*}{$\begin{array}{l}\text { Value of } \\
\text { sociality }\end{array}$} & Pearson's correlation & -.087 & -.245 & $-.376^{* * *}$ \\
\hline & Value (2-sides) & .557 & .093 & .008 \\
\hline & $\mathrm{N}$ & 248 & 248 & 248 \\
\hline \multirow{3}{*}{$\begin{array}{l}\text { Value of } \\
\text { security }\end{array}$} & Pearson's correlation & -.025 & $.610 *$ & -.157 \\
\hline & Value (2-sides) & .867 & .045 & .288 \\
\hline & $\mathrm{N}$ & 248 & 248 & 248 \\
\hline \multirow{3}{*}{$\begin{array}{l}\text { Value of } \\
\text { traditions } \\
\text { supporting }\end{array}$} & Pearson's correlation & -.178 & $.371 *$ & .002 \\
\hline & Value (2-sides) & .225 & .024 & .989 \\
\hline & $\mathrm{N}$ & 248 & 248 & 248 \\
\hline \multirow{3}{*}{$\begin{array}{l}\text { Value of } \\
\text { social culture }\end{array}$} & Pearson's correlation & -.055 & $.396^{*}$ & .120 \\
\hline & Value (2-sides) & .711 & .017 & .418 \\
\hline & $\mathrm{N}$ & 248 & 248 & 248 \\
\hline
\end{tabular}

As can be seen from the statistical data (Table 1) in the group of managers of $\mathrm{X}$ generation, the following values are expressed: achievements correlate with a rational type of economic behavior $\left(0,311^{*}\right)$. Managers are careful and prudent about money and related relationships. These managers are important in goal setting processes in project management.

The higher the value of social contact $\left(-0.376^{* *}\right)$ and conformity $\left(-0.405^{* *}\right)$, but low the value of self-determination $(0.437 * *)$, the more likely managers to exhibit an alarming type of economic behavior. They most likely worry about financial resources, have excessive control of their finances. Such managers must perform controlling functions in a team.

Saving type of economic behavior correlates with the values of security $\left(0.610^{*}\right)$, social culture $\left(0.396^{*}\right)$ and support $\left(0.371^{*}\right)$. People of such type have a strategy of saving financial resources, spend resources only on significant objects. Such managers will play the role of evaluators of the opportunities of projects.

We also considered the relationship between values and the type of economic behavior in managers of Generation Y, the results of the analysis are shown in Table 3. 
Table 3. Significant correlations between values and type of economic behavior in Generation $Y$ managers.

\begin{tabular}{|c|c|c|c|c|}
\hline \multirow[t]{2}{*}{ Indicators } & $\begin{array}{l}\text { Type of economic } \\
\text { behavior }\end{array}$ & Alarming & Negative & Therapeutic \\
\hline & Pearson's correlation & .114 & $.804^{* *}$ & -.016 \\
\hline \multirow[t]{2}{*}{ Value of pleasure } & Value.(2-sides) & .418 & .594 & .600 \\
\hline & $\mathrm{N}$ & 412 & 412 & 412 \\
\hline \multirow{3}{*}{$\begin{array}{l}\text { Value of social } \\
\text { power }\end{array}$} & Pearson's correlation & -.170 & -.187 & $.326^{*}$ \\
\hline & Value.(2-sides) & & & \\
\hline & $\mathrm{N}$ & 412 & 412 & 412 \\
\hline \multirow{2}{*}{$\begin{array}{l}\text { Value of self- } \\
\text { determination }\end{array}$} & Pearson's correlation & -.324 & -.211 & .332 \\
\hline & $\mathrm{N}$ & 412 & 412 & 412 \\
\hline \multirow{3}{*}{$\begin{array}{l}\text { Value of } \\
\text { stimulation }\end{array}$} & Pearson's correlation & $.382^{* *}$ & .010 & $.430^{* *}$ \\
\hline & Value.(2-sides) & .017 & .418 & .594 \\
\hline & $\mathrm{N}$ & 412 & 412 & 412 \\
\hline \multirow{3}{*}{$\begin{array}{l}\text { Value of } \\
\text { conformity }\end{array}$} & Pearson's correlation & .033 & $.778^{* *}$ & -.104 \\
\hline & Value.(2-sides) & .909 & .002 & .161 \\
\hline & $\mathrm{N}$ & 412 & 412 & 412 \\
\hline \multirow{3}{*}{ Value of sociality } & Pearson's correlation & $-.326^{*}$ & -.011 & $.378^{* * *}$ \\
\hline & Value.(2-sides) & .033 & .913 & .458 \\
\hline & $\mathrm{N}$ & 412 & 412 & 412 \\
\hline \multirow{3}{*}{ Value of security } & Pearson's correlation & .129 & $.345^{*}$ & $-.743^{* *}$ \\
\hline & Value.(2-sides) & .008 & .428 & .470 \\
\hline & $\mathrm{N}$ & 412 & 412 & 412 \\
\hline \multirow{3}{*}{$\begin{array}{l}\text { Value of traditions } \\
\text { supporting }\end{array}$} & Pearson's correlation & $-.409^{* *}$ & $.525^{* *}$ & -.016 \\
\hline & Value.(2-sides) & .867 & .045 & .288 \\
\hline & $\mathrm{N}$ & 412 & 412 & 412 \\
\hline \multirow{3}{*}{$\begin{array}{l}\text { Value of social } \\
\text { culture }\end{array}$} & Pearson's correlation & $.416^{* * *}$ & .273 & -.320 \\
\hline & Value.(2-sides) & .017 & .418 & .594 \\
\hline & $\mathrm{N}$ & 412 & 412 & 412 \\
\hline \multirow{3}{*}{$\begin{array}{l}\text { Value of } \\
\text { spirituality }\end{array}$} & Pearson's correlation & -.160 & -.384 & $.440^{*}$ \\
\hline & Value.(2-sides) & .225 & .024 & .989 \\
\hline & $\mathrm{N}$ & 412 & 412 & 412 \\
\hline
\end{tabular}

The correlations in Table 2 show that managers from Generation $\mathrm{Y}$ who have high values on the value scales: stimulation $\left(0.382^{* *}\right)$, support for traditions $(0.409 * *)$, social culture $\left(0.416^{* *}\right)$, are most likely to prefer an alarming type of economic behavior: they often worry about financial resources. Such managers are important in the process of creating and shaping the corporate culture of a company.

Managers who have high values on the value scales: pleasure $\left(0.804^{* *}\right)$, conformism $\left(0.778^{* *}\right)$, security $\left(0.345^{*}\right)$, support for traditions $\left(0.525^{* *}\right)$, are most likely to prefer a negative type of economic behavior. These managers will prefer routine work.

Managers of Generation Y with high values on the value scales: social power $\left(0.326^{*}\right)$, sociality $\left(0.378^{* *}\right)$, security $\left(-0.743^{* *}\right)$, stimulation $\left(0.430^{* *}\right)$, spirituality $\left(0.440^{*}\right)$ are most likely to prefer a therapeutic type of economic behavior. These are individuals who are good at discussing new ideas and providing psychological support to other team members.

After that, we measured the life meanings of managers. The results are shown in Figure 1. In the first group of Generation $\mathrm{X}$ the most expressed life meaning are: hedonism, status meanings and family ones. In the group of Generation $\mathrm{Y}$ the most expressed ones are: altruism, existential and cognitive. 


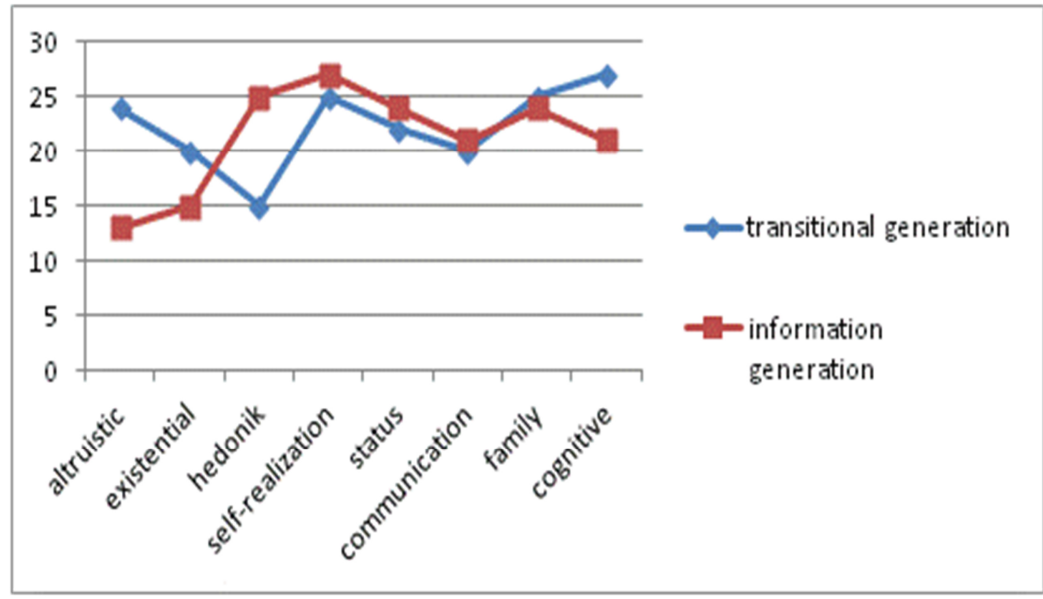

Fig. 1. Expressions of life meanings in generations groups.

Our attention was drawn to the results showing that in the group of Generation $\mathrm{X}$ altruistic meanings $(\mathrm{U}=0.012)$ and cognitive meanings were significantly different; hedonistic meanings $(\mathrm{U}=0.028)$ were less expressed. In the Generation $\mathrm{Y}$ group, altruistic meanings are less expressed $(U=0.034)$, but hedonistic meanings are more expressed $(U=$ 0.021 ). We can conclude that economic behavior of the managers of Generation $\mathrm{X}$ is aimed more at finding the greatest possible loyalty to the company, and less at searching for comfort and pleasure from work. For managers of Generation Y, economic behavior is directed at more selfish aspirations, achieving personal results, and enjoying work. This result is combined with the predominance of the innovative mentality of Generation Y. Both groups show the meaning of economic behavior - self-realization and status.

Summarizing the data obtained, we can hypothetically assume a correspondence between the type of mentality and the methodology of project management. The result is shown in Table 4.

Table 4. Characteristic features of the economic mentality type of managers of different generations.

\begin{tabular}{|l|c|c|c|c|c|c|}
\hline & \multicolumn{5}{|c|}{ Generation X } & \multicolumn{3}{c|}{ Innovative } \\
\hline $\begin{array}{l}\text { Mentality } \\
\text { type }\end{array}$ & \multicolumn{3}{|c|}{ Traditional } \\
\hline $\begin{array}{l}\text { Type of } \\
\text { economic } \\
\text { behavior }\end{array}$ & Rational & Alarming & Saving & Alarming & Negative & $\begin{array}{c}\text { Therapeut } \\
\text { ic }\end{array}$ \\
\hline Values & $\begin{array}{c}\text { Achievem } \\
\text { ents }\end{array}$ & $\begin{array}{c}\text { Self- } \\
\text { determinatio } \\
\text { n, } \\
\text { security }\end{array}$ & $\begin{array}{c}\text { Non- } \\
\text { contact, } \\
\text { nonconform } \\
\text { ism }\end{array}$ & Family & Hedonism & $\begin{array}{c}\text { Self- } \\
\text { realization } \\
\text {, status }\end{array}$ \\
\hline Senses & $\begin{array}{c}\text { Cognitive } \\
\text { Self- } \\
\text { realization, } \\
\text { status }\end{array}$ & $\begin{array}{c}\text { Altruism } \\
\text { from } \\
\text { traditions }\end{array}$ & $\begin{array}{c}\text { Pleasure, } \\
\text { conformis } \\
\text { m }\end{array}$ & $\begin{array}{c}\text { Social } \\
\text { power }\end{array}$ \\
\hline $\begin{array}{l}\text { Economic } \\
\text { mentality }\end{array}$ & Plan! & Be careful! & Profitability & Be bright! & $\begin{array}{c}\text { Work with } \\
\text { pleasure }\end{array}$ & $\begin{array}{c}\text { Be the } \\
\text { first! }\end{array}$ \\
\hline $\begin{array}{l}\text { Methodol } \\
\text { ogy }\end{array}$ & Agile & Muda & Kanban & Scrum & Waterfall & Six Sigma \\
\hline
\end{tabular}




\section{Discussion}

In the study, we presented the economic mentality as a construct that includes the values, meanings, and type of economic behavior of managers belonging to different generations. This does not contradict the earlier definitions of economic mentality and its structure. For example, Nureev (2001) [20] writes that the main elements of the national economic mentality are consumption stereotypes, norms and patterns of social interaction, organizational forms of economic activity, value-motivational attitude to work and to wealth, the degree of susceptibility to foreign experience. Oleynik (2012) [21] defines the economic mentality as the specificity of the consciousness of the population, which is formed historically and is manifested in the unity of conscious and unconscious values, norms and attitudes that are displayed in the behavior of the population. It includes consumption stereotypes, norms and patterns of interaction, organizational forms, valuemotivational attitude to work and wealth.

In our study, we explained the relationship between economic mentality and project management. When we identified certain types of economic behavior in managers belonging to different generations, we showed that this factor is non-situational in economic relations. This somewhat contradicts the research of Crusius et al. (2011) [22]. They argue that more attention should be paid to understanding the reasons for economic behavior in explaining the causes of certain types of behavior. The authors illustrate that situational context is a central factor in determining the mental processes that regulate behavior.

The construct of mentality cannot be identified directly. It manifests itself more at the group level and less at the individual level. We have constructed it from several components: the type of mentality, the type of economic behavior, values and meanings. That was challenging.

Regarding generations, I would like to note that today there is a number of works in which this notion is criticized. For example, Rudolph et al. (2018) [23] note that generational difference theories are based on erroneous assumptions about the role that "generations» play in shaping outcomes that are manifested at the individual level. Here we agree with the authors and believe that generation is a large group and the influence on individual manifestations is not very strong. The authors also note that there are no sufficient methods today to study whether there are differences between generations with sufficient accuracy. We compared individual groups in each generation. They may differ in different cultures, regions, etc. But the overall context of the nuclear components of the mentality will always be similar.

\section{Conclusions}

The development of economic activity of people is caused by features of their economic mentality. We understand economic mentality as a complex system of combining valuesemantic components and socio-psychological characteristics aimed at creating new or changing accepted economic concepts, notions, ways of thinking or economic behavior, implemented in the economic activity of generations. The economic activity of people leads to the formation of an economic model, which is the basis of any business. What factors determine the priority of these models is unclear. This can be explained by the peculiarities of the economic mentality of representatives of different generations. Economic mentality combines features of values and meanings, economic behavior of managers, representatives of generations.

In the empirical part of the study, it was shown that managers of Generation $\mathrm{X}$ have a traditional mentality. Managers of Generation $\mathrm{Y}$ have an innovative type of mentality. For 
the entire sample, the most dominant meaning is that of self- realization and status. The least important for the $\mathrm{X}$ generation are hedonistic meanings; for Generation $\mathrm{Y}$ - altruistic meanings.

Empirically, it is established that the most dominant values for managers of Generation $\mathrm{X}$ are: achievement, social subordination, self-determination, stimulation, nonconformism, less value of social contacts, security, and tradition. Managers of Generation Y have the most prominent values: pleasure, achievement, social power, self-determination, stimulation, conformity, sociality, tradition, social culture, spirituality. However, they are combined in different ways with the types of economic behavior. In the group of managers of Generation $\mathrm{X}$ the most expressed are: rational, alarming, saving types of economic behavior. The group of managers of Generation $\mathrm{Y}$ is dominated by alarming, negative, and therapeutic types of economic behavior. The predominance of alarming type of economic behavior in both groups can be explained by market instability.

The selected types of components of the economic mentality of managers can be taken into account in projecting activity to increase its effectiveness.

\section{References}

1. Project Management Institute Inc. A Guide to the Project Management Body of Knowledge (PMBOK guide, 2017)

2. D. Muslihat, 7 Popular Project Management Methodologies And What They're Best Suited For (2018) https://zenkit.com/en/blog/7-popular-project-managementmethodologies-and-what-theyre-best-suited-for/

3. V.I. Pishchik, The mentality of generations in fluid modernity (scientific monograph) (INFRA-M, Moscow, 2019) doi: 10.12737/monography_5ba0ee24675441.11909669

4. A.L. Zhuravlev, A.L., V.P. Poznyakov, Psychological journal 39(1), 15-25 (2018) doi:10.7868/S0205959218010026

5. L. Batrancea, A. Nichita, J. Olsen, C. Kogler, S. Zukauskas, Journal of Economic Psychology 74, 102191 (2019). doi: 10.1016/j.joep.2011.02.009

6. D. Fetchenhauer, O.H. Azar, G. Antonides, D. Dunning, F.R.H., S. Lea, F. Ölander, Journal of Economic Psychology 33(3), 695-699 (2012) doi: 10.1016/j.joep.2011.09.006

7. E. Kirchler, Economic psychology (Cambridge University Press, 2018) doi.org/10.1017/9781139629065

8. C. Lisciandra, Studies in History and Philosophy of Science 72A, 11-21 (2018) doi: 10.1016/j.shpsa.2018.01.010

9. G.E. Bolton, A. Ockenfels, Journal of Economic Psychology 33(3), 665-676 (2012) doi:10.1016/j.joep.2011.09.003

10. D. Dunning, D. Fetchenhauer, T.M. Schlösser, Journal of Economic Psychology 33(3), 686-694 (2012) doi:10.1016/j.joep.2011.09.005

11. R. Roberto Farias de Toledo, H.L. Miranda Junior, J.R. Farias Filho, H. Gomes Costa, A scientometric review of global research on sustainability and project management dataset (2019) doi:10.1016/j.dib.2019.104312

12. H.M. Gharaibeh, International Journal of Project Organisation and Management 8(1), 87-102 (2016) doi: 10.1504/IJPOM.2016.075785

13. F. Pargar, J. Kujala, K. Aaltonen, S. Ruutu, International Journal of Project Management 37, 716-730 (2019) doi:10.1016/j.ijproman.2018.12.006 
14. D.P. Velayudhan, S. Thomas, International Journal of Project Organisation and Management 10(1), 82-92 (2018) doi: 10.1504/IJPOM.2018.090377

15. B.J. Galli, M. Amin Kaviani, L.A. Ocampo, International Journal of Project Organisation and Management 11(2), 110-139 (2019) doi: 10.1504/IJPOM.2019.100590

16. B.A. Kaifi, W.A. Nafei, N.M. Khanfar, M.M. Kaifi, International Journal of Business \& Management 7(24), 88-93 (2012) doi:10.5539/ijbm.v7n24p88

17. N.M. Lebedeva, A.N. Tatarko, Culture as a factor of social progress (JSC «Justicinform», Moscow, 2009)

18. V.Yu. Kotlyakov, Bulletin of the Kemerovo State University 2(54), 148-153 (2013)

19. S.H. Shwartz, Online Readings in Psychology and Culture 2 (2012) http://scholarworks.gvsu.edu/orpc/vol2/iss1/11

20. R.M. Nureyev, Critique of the basic premises of modern macroeconomic theories (Institute of Economics of the Russian Academy of Sciences, Moscow, 2014)

21. A.N. Oleynik, Institutional Economics (Infra-M Publ. House, Moscow, 2012)

22. J. Crusius, F. van Horen, T. Mussweiler, Journal of Economic Psychology 33, 677-685 (2011) doi:10.1016/j.joep.2011.09.004

23. C.W. Rudolph, R.S. Rauvola, H. Zacher, The Leadership Quarterly 29(1), 44-57 (2018) doi: 10.1016/j.leaqua.2017.09.004 